\title{
THE EFFECT OF TRANSFORMATIONAL LEADERSHIP AND INFORMATION TECHNOLOGY ON ORGANIZATIONAL LEARNING AND ORGANIZATIONAL CHANGE, AND ITS IMPACT ON EMPLOYEE JOB SATISFACTION (STUDY ON PT PUPUK KALTIM EMPLOYEES)
}

\author{
Achmad Bakir Pasaman ${ }^{1}$, Umar Nimran ${ }^{2}$, Kusdi Raharjo ${ }^{2}$ and \\ Hamidah Nayati Utami ${ }^{2}$ \\ ${ }^{1}$ Doctoral Candidate of Faculty of Administrative \\ Sciences \\ University of Brawijaya \\ ${ }^{2}$ Professors of Faculty of Administrative Sciences \\ University of Brawijaya
}

\begin{abstract}
The purpose of this study is to examine the effect of transformational leadership and information technology on organizational learning and organizational change and its impact on employee job satisfaction at PT. Pupuk Kaltim. The study is conducted by analyzing the effect between variables consisting of 2 (two) exogenous variables: Transformational Leadership (X1) and Information Technology (X2), and 3 (three) endogenous variables: Organizational Learning (Y1), Organizational Change (Y2) and Employee Job Satisfaction (Y3). This study is designed to answer the problem statements that have been formulated. The study method is an explanatory research. The population is employees of PT. Pupuk Kaltim, where the size of its sample is of 207 respondents. The data is collected using proportional stratified random sampling method to find the effect between exogenous variables and endogenous variables. The findings of the study are from the 9 (nine) hypotheses tested, 8 (eight) hypotheses have significantly affected on the variables studied. The only one which has no significant effect is Transformational Leadership on Employee Job Satisfaction, where it needs to be mediated by organizational learning and organizational change.
\end{abstract}

Keywords: Transformational Leadership, Information Technology, Organizational Learning, Organizational Change, Employee Job Satisfaction 


\section{INTRODUCTION}

The phenomenon of business competition occurs in various sectors and determines the fate of the business continuity of the company. Many challenges will be faced by organizations in the current era of disruption, especially in the Industrial Age 4.0, namely the challenges within the organization itself, domestic challenges and global challenges (Sukoharsono, 2008). The fluctuating global financial situation and the turmoil of geo-political conflicts have an impact on the condition of the Indonesian economy. In addition to global challenges, Indonesian companies also face challenges in the country, , such as the availability of depleting natural resources, a less conducive domestic security situation, fluctuating macro and microeconomic conditions. These things certainly greatly affect competitiveness for business continuity.The current industrial era has entered the Industrial Age 4.0 which is very different from the previous industrial era (Sukoharsono, 2008). In the Industrial Age 4.0, the industry was developed based on digitalization and automation, all of which were based on Information Technology; Internet of things, robotization, and and artificial intelligence is something that is commonly used in the Industrial Age 4.0. In the Industrial Age 4.0 employees have characteristics that are very different from the previous era. Employees feel they want to be treated as individuals with their own values and goals, not as factors of production. Employees in this era generally tend to do knowledge-based work and are less fond of routine work. Functional hierarchical organizations such as those developed by Winston Taylor since the Industrial Age 2.0 have become less suitable for the current situation so companies need organizational transformation. Companies facing the challenges of the disruption era have the time to say goodbye to the functional hierarchy and welcome a new structure that underlies the work of knowledge and creative, talented and energetic people who work for joint missions (Kolind \& Botter, 2017; Sukoharsono, 2015).

Leadership and competent human resource factors are the main factors and greatly influence the organizational learning process and organizational changes so that they can be highly competitive. Leadership is one of the main factors in bringing positive change to the organization. If there is no leadership in the organization, the employee will not change in the desired direction and can even experience negative changes. Leadership skills are also able to move employees in the right direction, in accordance with the vision and mission of the organization and motivate them to continue to improve performance and innovate. 
Factors of competent human resources in accordance with company standards will have a positive effect on the effectiveness of the learning process and organizational changes in order to improve competitiveness. Benchmarks for the success of learning and organizational change can be seen from employee job satisfaction (Robbins, 2006).

Generation gap can also be a challenge in human resources within a company. The current generation gap is the baby boomer's generation, generation $\mathrm{X}$, and millennial who have different perspectives in running an organization. Millennial have very different characters from previous generations. When the baby boomers have retired, generation $\mathrm{X}$ and millennial will gradually begin to take over leadership in running the organization. The baby boomer generation that is meant here is the generation born in 1946-1964, generation X with birth in 1965-1979, millennial or called generation Y with births from 1980 to 1995 (Ubl, et al 2017).

The originality of this study lies in the selection of PT Pupuk Kaltim as the object of research. PT Pupuk Kaltim as one of the strategic and vital industries that plays an important role in realizing national food sovereignty is also facing various challenges both internal and external. PT Pupuk Kaltim which is a member of the Holding of PT Pupuk Indonesia (Persero) is listed as the largest producer of Ammonia and Urea in Indonesia with urea production capacity of 3.4 million tons per year, ammonia

of 2.7 million tons and NPK of 350 thousand tons per year where $40 \%$ of the total urea production capacity is allocated to two thirds of Indonesia's territory, especially the eastern region (Pupuk Kaltim. 2017).

To maintain competitiveness and anticipate the above, PT Pupuk Kaltim needs to carry out the learning process. PT Pupuk Kaltim has facilitated the existence of information technology to improve the efficiency of current business processes. PT Pupuk Kaltim has made various efforts to build the image and existence of the company at national and international levels. PT Pupuk Kaltim has won several reputable awards at national and international levels such as: SNI Award Platinum 2016 and 2017 honors, Propernas 2017 predicate Gold, IFA 2017 Protect \& Sustain from the International Fertilizer Association with Product Excellence Stewardship predicate. The award is the first received by the fertilizer industry in Indonesia. Several other awards were also obtained, including: Security System Gold Award Factory, Platinum and Gold Predicate Award, CSR Award, Annual Report Award, Sustainability Award and others. By obtaining several awards, it can increase 
customer confidence in the competencies and excellence of PT Pupuk Kaltim products both at national and international levels. This is the result of an ongoing organizational learning process supported by all company work units.

Based on a number of reasons stated above, study will be carried out in depth on the condition of the PT Pupuk Kaltim organization from an employee perspective. The study scheme in this dissertation will identify how transformational leadership and information technology influence organizational learning and change at PT Pupuk Kaltim in employee perceptions and its impact on employee job satisfaction.

This study was conducted to determine the effect of variables consisting of 2 (two) exogenous variables: Transformational Leadership (X1) and Information Technology (X2), and 3 (three) endogenous variables: Organizational Learning (Y1), Organizational Change (Y2) and Employee Job Satisfaction (Y3). In more detail the objectives of this study are:

1. To test and explain the effect of transformational leadership on organizational learning.

2. To test and explain the effect of transformational leadership on organizational change.

3. To test and explain the effect of transformational leadership on employee job satisfaction.

4. To test and explain the influence of organizational learning on organizational change.

5. To test and explain the influence of information technology on organizational learning.

6. To test and explain the influence of information technology on organizational change.

7. To test and explain the influence of information technology on employee job satisfaction.

8. To test and explain the influence of organizational change on employee job satisfaction.

9. To test and explain the influence of organizational learning on employee job satisfaction. 


\section{RESEARCH METHOD}

This study is designed to answer the problems that have been formulated. This study is using explanatory method to explain the relationship between variables through testing hypotheses. The data collected is using proportional stratified random sampling method to find the relationship between independent variables and dependent variable.

The study is using quantitative approach which starts from theory and then uses deductive logic to be derived into study hypotheses which are accompanied by measurement and operationalization of variables. Then generalization is based on statistics so that conclusions can be drawn as a result of study findings. This study was conducted to explain the influence of Transformational Leadership, Information Technology, Organizational Learning, Organizational Change and Employee Job Satisfaction. To answer the formulation of the problem, the objectives to be achieved and test the hypothesis, this study was designed with the following design:

a. In terms of data collection techniques, this study is a type of survey that takes samples from a population using a questionnaire as the main data collection tool (Singarimbun in Singarimbun and Effendi, 2008). In terms of the objectives to be achieved, this study is using an explanatory approach to explain its effects between exogenous and endogenous variables through hypothesis testing (Singarimbun in Singarimbun and Effendi, 2008).

b. Based on the data analysis, this study is using an analytical approach to analyze sample data with inductive statistics with generalized descriptive statistics for population conclusions (Arikunto, 2002).

Based on a conceptual framework of empirical and theoretical studies and in accordance with the problems that have been proposed in the future, this study is designed so that it can be used to analyze several exogenous variables and endogenous variables. Endogenous variables in this study are: Organizational Learning, Organizational Change and Employee Job Satisfaction, while the exogenous variables in this study are: Transformational Leadership and Information Technology. 


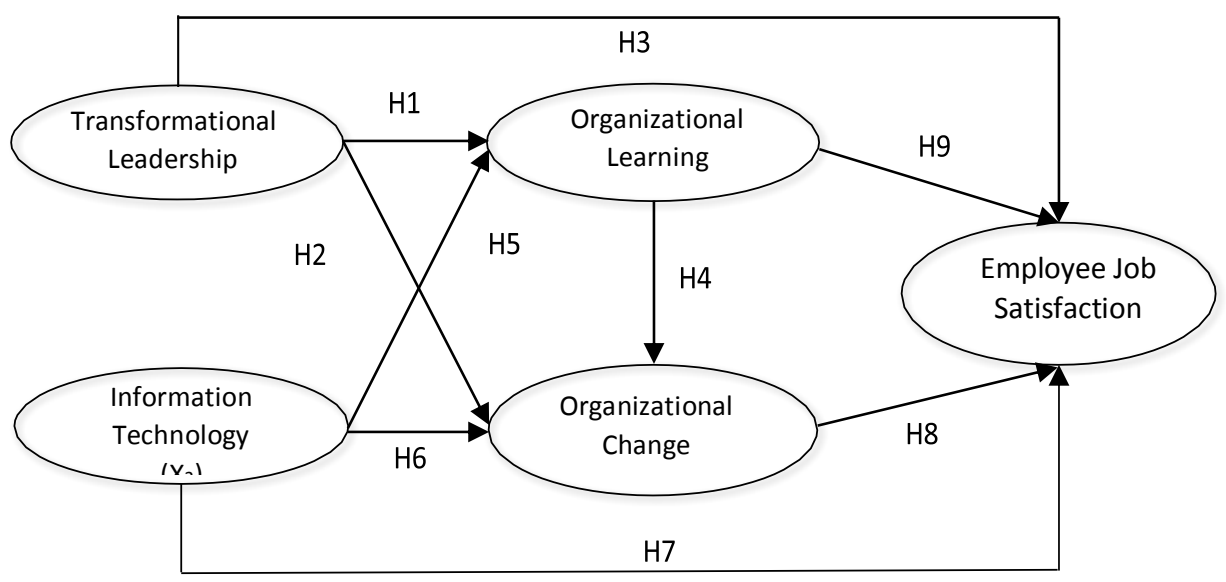

Figure 1 Research Hypothesis Model

Based on this empirical study, the development of the conceptual model and the hypothesis model that have been stated above, this study will test a number of hypotheses, namely:

a. Transformational Leadership has a significant effect on Organizational Learning (H1).

b. Transformational Leadership has a significant effect on Organizational Change (H2).

c. Transformational Leadership has a significant effect on Employee Job Satisfaction (H3).

d. Organizational Learning has a significant effect on Organizational Change (H4).

e. Information Technology has a significant effect on Organizational Learning (H5).

f. Information Technology has a significant effect on Organizational Change (H6).

g. Information Technology has a significant effect on Employee Job Satisfaction (H7).

h. Organizational Change has a significant effect on Employee Job Satisfaction (H8).

i. Organizational Learning has a significant effect on Employee Job Satisfaction (H9). 


\section{Method of collecting data}

This study sampling is taken using probability sampling where each unit in the population has an opportunity or in other words each sample has the same possibility to be chosen (Etikan, et al 2015). Based on PT Pupuk Kaltim's Human Resources Information System (HRIS), the number of employees recorded is of 1970, consisting of Grade I to Grade VII. The population studied is of 429 employees consisted of 3 (three) grade levels: Grade I (General Managers), Grade II level (Managers) and Grade III (Superintendents).

The minimum number of samples is determined by using the Slovin formula (Umar, 2005). The sample size obtained in this study is of 207 employees. The number of samples in detail is shown in the table below:

Table 1 Population and Research Sample

\begin{tabular}{|c|c|c|c|}
\hline No & Grade & Population & Sample \\
\hline 1 & Grade I & 39 & 19 \\
\hline 2 & Grade II & 112 & 54 \\
\hline 3 & Grade III & 278 & 134 \\
\hline & Total & $\mathbf{4 2 9}$ & $\mathbf{2 0 7}$ \\
\hline
\end{tabular}

In Table 1 above, the selection of samples for Grade I to Grade III is done with proportional stratified random sampling. This study uses questionnaires with closed questions and distributed electronically through company e-mails by attaching a cover letter sent to each respondent's personal e-mail without mentioning the name of the researcher to obtain independent results from this study. Furthermore, the respondent is given the opportunity for 2 (two) weeks to fill up all the questions without being missed. For employees who have not filled out the questionnaire will be automatically expedited by the system (there are alerts for those who have not responded) so that the questionnaire can be collected thoroughly. After being declared complete and validated by the system, the results of the questionnaire were randomly processed by the system by ignoring the Grade I and II employees seconded in subsidiaries or foundations so that a sample of 207 representing Grade I to Grade III was obtained. 


\section{RESULTS AND DISCUSSION}

\section{Results of Structural Equation Model Analysis with WarpPLS}

Structural Equation Model or SEM-WarpPLS is a structural equation model based on components or variants. The evaluation of the SEM-WarpPLS model in this study begins with a measure of fit which aims to test whether the study instrument is valid or reliable in explaining latent variables. Evaluation of the measurement model is done by examining the convergent validity value, discriminant validity, and composite reliability. Examination of the measure of fit in the overall model (overall model) is a measure of goodness of fit which is a combination of measurement models and structural models with R-squared and Q-squared tests. Overall of goods of fit tests is valid and reliable.

\section{Results of Measure of Fit Structural Model}

The feasibility testing of the model is structurally measured using R-squared and Q-squared which is equivalent to the total determination coefficient in path analysis or in PLS. The R-squared value shows the total diversity of all variables that can be explained by the structural model. Q-squared values range from -1 to 1 , where the greater the Q-squared value (near one), the greater the total diversity that can be explained by the model.

The R-squared value is the determination coefficient which shows how much the percentage of endogenous construct variance can be explained by the construct which is hypothesized to influence it (exogenous). The higher the Rsquared value, the better the study model. R-squared values only exist for endogenous variables or constructs. Based on the feasibility testing of the model as shown in Table 2 below, the R-squared values were obtained for Organizational Learning (Y1) of 0.700, Organizational Change (Y2) of 0.766 and Employee Job Satisfaction (Y3) of 0.996. 
Table 2 Result of Measure of Fit

\begin{tabular}{|c|c|c|c|c|}
\hline No & Variable & R-squared & Adj R-squared & Q-squared \\
\hline 1 & X1 & - & - & - \\
\hline 2 & X2 & - & - & - \\
\hline 3 & Y1 & 0.700 & 0.699 & 0.701 \\
\hline 4 & Y2 & 0.766 & 0.764 & 0.766 \\
\hline 5 & Y3 & 0.996 & 0.996 & 0.989 \\
\hline
\end{tabular}

Thus it can be interpreted as follows:

a. R-squared for Organizational Learning (Y1) of 0.700 means that the Organizational Learning variance can be explained by 70.00 percent by the variance of Transformational Leadership and Information Technology.

b. R-squared for Organizational Change (Y2) of 0.766 means that the variance of Organizational Change can be explained by 76.60 percent by the variance of Transformational Leadership, Information Technology and Organizational Learning.

c. R-squared Employee Job Satisfaction (Y3) of 0.996 means that the variance of Employee Job Satisfaction is 99.60 percent can be explained by the variance of Transformational Leadership, Information Technology, Organizational Learning and Organizational Change.

While the results of the Q-squared value test, which is the value usually referred to as Stoner Geisser Coefficient is the nonparametric value obtained through the blindfolding algorithm. Q-squared is used to assess the predictive validity or relevance of a set of (exogenous) predictor latent variables on the endogenous variables. Q-squared is an analogue of R-squared but only if it is obtained by resampling. Q- squared can be negative while R-squared is always positive. Models with good predictive validity must have a Q-squared value that is greater than zero (Hair et al., 2011). The test results of the study model show good predictive validity because Q-squared has values above zero that are $0.701,0.766$ and 0.989 . 


\section{Hypothesis Testing Results}

Based on the results of the model suitability test, the proposed conceptual framework meets the requirements or can be used as a measurement model in this study

Figure 2 Result of Structural Model

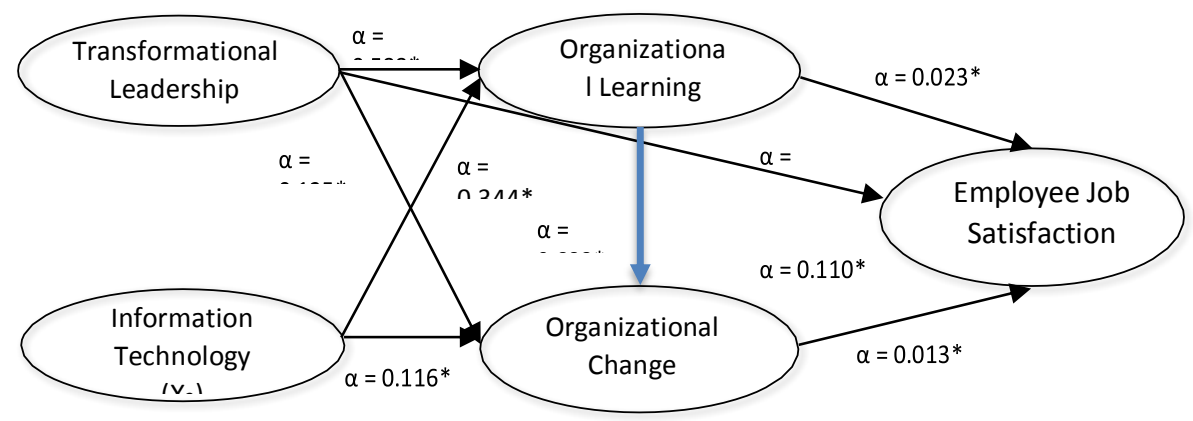

Note:

* = Estimate path coefficient $(\alpha)$ which gives p-value below 5\%

$\longrightarrow=$ novelty

Table 3. Inner-Model Testing Results

\begin{tabular}{|c|c|c|c|c|c|}
\hline $\begin{array}{c}\text { Hypothes } \\
\text { es }\end{array}$ & $\begin{array}{c}\text { Relation } \\
\text { between } \\
\text { Variable }\end{array}$ & $\begin{array}{c}\text { Path } \\
\text { Coefficient } \\
(\boldsymbol{\alpha})\end{array}$ & SE & p-value & Remarks \\
\hline $\mathrm{H} 1$ & $\mathrm{X} 1 \rightarrow \mathrm{Y} 1$ & 0.588 & 0.045 & $0.001^{* *}$ & Significant \\
\hline $\mathrm{H} 2$ & $\mathrm{X} 1 \rightarrow \mathrm{Y} 2$ & 0.125 & 0.048 & $0.005^{* *}$ & Significant \\
\hline $\mathrm{H} 3$ & $\mathrm{X} 1 \rightarrow \mathrm{Y} 3$ & 0.042 & 0.048 & 0.094 & $\begin{array}{c}\text { Not } \\
\text { Significant }\end{array}$ \\
\hline $\mathrm{H} 4$ & $\mathrm{Y} 1 \rightarrow \mathrm{Y} 2$ & 0.688 & 0.044 & $0.001^{* *}$ & Significant \\
\hline $\mathrm{H} 5$ & $\mathrm{X} 2 \rightarrow \mathrm{Y} 1$ & 0.344 & 0.046 & $0.001^{* *}$ & Significant \\
\hline $\mathrm{H} 6$ & $\mathrm{X} 2 \rightarrow \mathrm{Y} 2$ & 0.116 & 0.048 & $0.008^{* *}$ & Significant \\
\hline $\mathrm{H} 7$ & $\mathrm{X} 2 \rightarrow \mathrm{Y} 3$ & 0.110 & 0.047 & $0.014^{* *}$ & Significant \\
\hline $\mathrm{H} 8$ & $\mathrm{Y} 2 \rightarrow \mathrm{Y} 3$ & 0.013 & 0.045 & $0.039^{* *}$ & Significant \\
\hline $\mathrm{H} 9$ & $\mathrm{Y} 1 \rightarrow \mathrm{Y} 3$ & 0.023 & 0.047 & $0.015^{* *}$ & Significant \\
\hline
\end{tabular}


$* *=$ Significant at the level of $0.05(5 \%)$

This study has 9 (nine) hypotheses, of which 8 (eight) hypotheses have significant results because the p-value is below the $5 \%$ level. Furthermore, the results of the structural modeltesting (inner-model) are shown in Table 3 and illustrated in Figure 2. The results of hypothesis testing show that the overall hypothesis proposed meets the criteria of significance, namely the p-value below the alpha value of 5\% (0.05), while the hypothesis (H3) of the test results is not significant because the p-value is above the $5 \%$ level, this caused by the largest distribution of respondent age above 48 years ( 69.08 percent) and the working period above 25 years (69.08 percent). Thus the $\mathrm{H} 3$ hypothesis accepts $\mathrm{H} 0$ which means that the variable transformational leadership (X1) does not affect the variable employee job satisfaction(Y3).

The results of the structural model obtained in this study indicate that all variables are significant at the 5\% level, except the Hypothesis-3 which has no significant effect. More about the description of inner-model testing can be stated in the following information.

1. Transformational Leadership (X1) has a significant effect on Organizational Learning (Y1) at the level of $\alpha=5 \%(\mathrm{p}$-value $=0.001)$. Its coefficient has a positive value. It indicates there is unidirectional relationship, so the higher the value of Transformational Leadership will have an effect on the higher the value of Organizational Learning.

2. Transformational Leadership (X1) has a significant effect on Organizational Change (Y2) at the level of $\alpha=5 \%$ (p-value $=0.005$ ). Its coefficient has a positive value. It indicates there is unidirectional relationship, so the higher the value of Transformational Leadership will have an effect on the higher the value of Organizational Change.

3. Transformational Leadership (X1) has no significant effect on Job Satisfaction (Y3) at the level of $\alpha=5 \%(p$-value $=0.094)$. Its coefficient has a positive value but not significant. It indicates there is no unidirectional relationship.

4. Organizational Learning (Y1) has a significant effect on Organizational Change (Y2): significant at the level of $\alpha=5 \%$ (p-value $=0.001$ ). Its coefficient has a positive value. It indicates there is unidirectional relationship, so the higher the value of Organizational Learning will have an effect on the higher the value of Organizational Change. 
5. Information Technology Influence (X2) has a significant effect on Organizational Learning (Y1): significant at level $\alpha=5 \%(\mathrm{p}$ - value $=0.001)$. Its coefficient has a positive value. It indicates there is unidirectional relationship, so the higher the value of Information Technology will have an effect on the higher the value of Organizational Learning.

6. Influence of Information Technology (X2) has a significant effect on Organizational Change (Y2): significant at level $\alpha=5 \%$ (p- value $=0.008)$. Its coefficient has a positive value. It indicates there is unidirectional relationship, so the higher the value of Information Technology will have an effect on the higher the value of Organizational Change.

7. Influence of Information Technology (X2) has a significant effect on Job Satisfaction (Y3): significant at the level of $\alpha=5 \%(\mathrm{p}$ - value $=0.014)$. Its coefficient has a positive value. It indicates there is unidirectional relationship, so the higher the value of Information Technology will have an effect on the higher the value of Employee Job Satisfaction.

8. Effect of Organizational Change (Y2) has a significant effect on Job Satisfaction (Y3): significant at the level of $\alpha=5 \%$ (p-value $=0.039$ ). Its coefficient has a positive value. It indicates there is unidirectional relationship, so the higher the value of Organizational Change the higher will have an effect on the value of Employee Job Satisfaction.

9. Effect of Organizational Learning (Y1) has a significant effect on Job Satisfaction (Y3): significant at the level of $\alpha=5 \%$ (p-value $=0.015$ ). Its coefficient has a positive value. It indicates there is unidirectional relationship, so the higher the value of Organizational Learning will have an effect on the higher the value of Employee Job Satisfaction.

\section{CONCLUSION}

Based on descriptive and inferential statistical analysis testing, this study can be concluded as follows:

1. Transformational Leadership has a significant effect on Organizational Learning. Leader characteristics are expected to be able to transfer company plans and strategies to run well so as to encourage more effective organizational learning. Respondents pay high attention to the style of Transformational Leadership, especially on indicators that appreciate the achievement and inspire a shared vision that has been felt quite well in the company. 
2. Transformational Leadership has a significant effect on Organizational Change. Through good Transformational Leadership from company leaders, the organization is able to transform or experience changes more effectively to challenges and changes in the environment both from within and from outside the company.

3. Transformational leadership has no significant effect on Employee Job Satisfaction. The characteristics of transformational leaders in delegating company tasks or strategies cannot be accepted directly by employees, but it must be mediated by organizational learning and organizational change.

4. Organizational Learning has a significant effect on Organizational Change. Culture, planning and operational good learning are a reflection of organizational learning. Through a learning plan at each level, the organization can respond more quickly to changes in anticipation of competition. Through learning, the organization is able to compete through continuous innovation and improvement activities.

5. Information Technology has a significant effect on Organizational Learning. An increasingly sophisticated and easily accessible information technology is able to drive the organizational learning process towards a better direction. Respondents see the existence of telecommunication equipment is good enough, but hardware and software still need to be improved. Rapid technological development must be well known and evaluated and is expected to be synergistic with the organizational learning process. If information technology continues to be updated and reliable, the learning process will be effectively implemented and employees have the convenience to access knowledge, experience and ideas from other employees.

6. Information Technology has a significant effect on Organizational Change. The existence of sophisticated, updated and reliable information technology can drive organizational change towards a better and more effective way. This requires the availability of hardware, software and telecommunications equipment that are available according to the needs of the organization.

7. Information Technology has a significant effect on Employee Job Satisfaction. Through the existence of reliable Information Technology can support employee performance to provide high-quality products and provide the best service for consumers. In addition, the existence of Information Technology also helps employees to deal with work complexity more 
effectively. Increased productivity through the existence of Information Technology will create a sense of satisfaction in employees through a more concise, flexible and updated workflow.

8. Organizational Change has a significant effect on Employee Job Satisfaction. Organizations need adaptation to changes in the environment, so it is important for organizations to inform and involve and engage employees in the organizational change process. It can build employee trust and job satisfaction because it is directly involved in the change process.

9. Organizational Learning has a significant effect on Employee Job Satisfaction. Organizational learning that is formed by a company that is structured, systematic and can be fulfilled(targetable) will be able to encourage employee job satisfaction. This study proves that organizational learning conducted by companies both directly and indirectly interacting with employees has created a more pleasant working atmosphere, thus creating an effective work climate for employees to carry out their responsibilities. In addition, a positive climate of organizational learning can create a collaborative culture among individual employees who support the organization to continue learning and better preparedness in the face of business competition. 


\section{REFERENCES}

Abbas, J., Muzaffar, A., Mahmood, H.K., Ramzan, M.A., \& Rizvi,S.S., 2014. Impact of Technology on Performance of Employees: A Case Study on Allied Bank Ltd, Pakistan. World Applied Sciences Journal 29 (2): 271276, 2014.

Bass, B.M \& Riggio,R.E. 2006.Transformational leadership. New Jersey: LEA. Publlisers Marwah.

Advani, A. (2015). Impact of Transformational and Transactional Leadership Styles on Employees' Performance of Banking Sector in Pakistan. Global Journal of Management and Business Research: A Administration and Management. Vol. 15 Issue 5.

Akhtar, Muhammad Naseer., Long Li Rong. 2015. The Impact of Organizational Change on Job Satisfaction, and Intention to Quit: A Mediating Role of Psychological Contract Violation. European Scientific Journal. Edition vol. 11 No.29 ISSN : $1857-7881$.

Bass, B.M \& Avolio,B.J.(1994). Improving organizational effectiveness: through transformational leadership. London: SAGE Publications TO

Al-Qura'an. 2015. A. The Impact of Transformational Leadership on Organizational Change Management: Case Study at Jordan Ahli Bank. Journal of Business and Management. Vol.17, Issue 12, PP 01-07

Alraja, Mansour Naser., \& Nayef Rage Alomiam. 2013. The Effect of Information Technology in Empowerment Public Sector Employees: A Field Study. Interdisciplinary Journal of Contemporary Research in Business Vol 5, No 1 May 2013

Asrar-ul-Haq, M., \& Kuchinke, K. P. (2016). Impact of leadership styles on employees' attitude towards their leader and performance: Empirical evidence from Pakistani banks. Future Business Journal, 2(1), 54-64

Bass, B.M. 1985. Leadership and performance beyond expectations, New York; The Free Press. 
Atmojo, M. (2012). The influence of transformational leadership on job satisfaction, organizational commitment, and employee performance. International research journal of business studies, 5(2).

Azanza, G., Moriano, J. A., \& Molero, F. (2013). Authentic leadership and organizational culture asdrivers of employees' job satisfaction. Revista de Psicología del Trabajo y de las Organizaciones, 29(2), 45-50.

Belias, D., \& Koustelios, A. (2014). Transformational leadership and job satisfaction in the banking sector: A review. International Review of Management and Marketing, 4(3), 187.

Carter, M. Z., Armenakis, A. A., Feild, H. S., \& Mossholder, K. W. (2013). Transformational leadership, relationship quality, and employee performance during continuous incremental organizational change. Journal of Organizational Behavior, 34(7), 942-958.

Bass, B.M.1990. Bass \& Stogdill's : Handbook of leadership. Theory,research \& managerial application". 3rd Ed. New York : The Free Press : A division of Macmillan, Inc.

Çetin, M., Karabay, M. E., \& Efe, M. N. (2012). The effects of leadership styles and the communication competency of bank managers on the employee's job satisfaction: The case of Turkish banks. Procedia-Social and Behavioral Sciences, 58, 227-235.

Chatman, Jennifer, dan Bersade. (1997). Employee Satisfaction, Factor Associated with Company Performance, Journal of Applied Pschology. New York.

Daff, Richard L. 2005. The Leadership Experience. Canada: Thomson.

Elgelal, K. S. K., \& Noermijati, N. 2015. The Influences of Transformational Leaderships on Employees Performance (A Study of the Economics and Business Faculty Employee at University of Muhammadiyah Malang). Asia-Pacific Management and Business Application, 3(1), 48-66.

Gupta, Shivani., \& Dr. Anju Singla. 2016. Organizational Change and Job Satisfaction: An Analysis of Mediating Effect of Organizational Trust. Indian Journal of Commerce \& Management Studies Volume VII Issue 3. 
Ilyas, M., \& Abdullah, T. (2016). The Effect of Leadership, Organizational Culture, Emotional Intellegence, and Job Satisfaction on Performance. International Journal of Evaluation and Research in Education, 5(2), 158164.

J. Pane \& S.D. Astuti. 2009. Pengaruh Budaya Organisasi, Kepemimpinan Transformasional, Dan Kompensasi Terhadap Kinerja Karyawan" (Studi pada Kantor Telkom Divre IV di Semarang). Telaah Manajemen Vol 6 Edisi 1, Maret 2009 hal 67-85.

Khosa, Z.M., Rehman, Z.U., Asad, A., Bilal, M.A., \& Hussain, N., (2015). The Impact of Organizational Change on the Employee's Performance in the Banking Sector of Pakistan. Journal of Business and Management. Volume 17, Issue 3.Ver. II (Mar. 2015), PP 54-61.

Kumari, Neeraj. 2011. Job Satisfaction of the employees at the Workplace, European Journal of Business and Management, (online). Vol 2, no,4 (www.iis.org). Diakses 2017.

Kute, D., \& Upadhyay, P., (2014). The Impact of Technological Changes on the Performance of the Employees in Commercial Printing Industry. Journal for Contemporary Research in Management, pp 67-72.

Mappamiring. (2015). Effect of Cultural Organization, Leadership and Motivation of Work on the Performance of Employees. International Journal of Academic Research in Business and Social Sciences, Vol. 5, No. 12 ISSN: 2222-6990

Metwally, Ayman H., Nada El-bishbishy, Yehia Sabri Nawar. 2014. The Impact of Transformational Leadership Style on Employee Satisfaction. The Business \& Management Review. Volume 5 Number 3.

Min Z. Carter et al. 2010. Transformational Leadership, Relationship Quality, and Employee Performance during Continuous Incremental Organizational Change. Department of Business Programs, Troy University, Troy, AL 36082 . 
Munir, R. I. S., Rahman, R. A., Malik, A. M. A., \& Ma'amor, H. (2012). Relationship between transformational leadership and employees' job satisfaction among the academic staff. Procedia-Social and Behavioral Sciences, 65, 885-890.

Parwanto dan Wahyuddin. 2011. Pengaruh Faktor- Faktor Kepuasan Kerja terhadap Kinerja Karyawan. Pusat Pendidikan Komputer Akuntansi Imka Dl Surakarta.

Daft.R.L,1995, Organization \& Theory and Design, 5th. Edition West Publishing Company.

Putra Salain, P. P., \& Wardana, M. 2014. Pengaruh Kepemimpinan Terhadap Budaya Organisasi Inovasi Dan Kinerja Karyawan (Studi Kasus Pada KANWIL PT. PEGADAIAN (PERSERO) DENPASAR). Buletin Studi Ekonomi, 19(1).

R, Ratna \& T, Kaur. 2016. The Impact of Information Technology on Job Related Health and Safety, Job Satisfcation, Performance, Productivity, and Work Life Balance. Journal of Business and Financial Affairs 2016.

Rose, Raduan Che., Naresh Kumar., Ong Gua Pak. 2009. The Effect of Organizational Learning on Organizational Commitment, Job Satisfaction, and Work Performance. The Journal of Applied Business Research.

Saptono, Edy., 2014. Kajian Kepemimpinan Transformasional, Komitmen Karyawan, Motivasi, Kepuasan Kerja, dan Kinerja Karyawan. Trikonomika Volume 13, No. 1, Juni 2014, Hal. 21-48.

Sukoharsono, Eko Ganis. 2008. Sistem Informasi Manajemen. (Management Information System). Malang: Surya Pena Gemilang.

Sukoharsono, Eko Ganis and Nur Nafiastuti Ristianti. 2015. Web-Based Enterprise Resource Planning (ERP) System In Action at the Case of A Catering Industry Company in Indonesia. The International Conference on Accounting and Finance, Bali 11-12 June

Yukl, G. 2005. Kepemimpinan dalam Organisasi. Edisi Kelima. Jakarta: Prenhallindo. 
Yukl, G. (2010). Kepemimpinan dalam organisasi (5th ed). (Budi Supriyanto, Trans). Jakarta: PT. Indeks 